\title{
Hubungan Perilaku Makan dan Status Gizi dengan Status Kesehatan Mental Siswa Sekolah Dasar
}

\section{Correlation between Dietary Habit and Nutritional Status with Mental Health Status of Elementary School Students}

\author{
Jufriana Yuwono Vera Adi ${ }^{1}$, Gelora Mangalik $^{2}$, Yulius Yusak Ranimpi ${ }^{3}$ \\ ${ }^{1,2}$ Fakultas Kedokteran dan Ilmu Kesehatan, Universitas Kristen Satya Wacana Salatiga, Indonesia \\ ${ }^{3}$ Fakultas Teologi, Universitas Kristen Satya Wacana Salatiga, Indonesia
}

\section{ARTICLE INFO}

\begin{tabular}{l} 
Article history: \\
Received date \\
20 Mar 2020 \\
Revised date \\
16 Apr 2020 \\
22 Apr 2020 \\
Accepted date \\
30 Apr 2020 \\
\hline
\end{tabular}

Keywords:

Eating behavior;

Elementary student;

Mental health of children;

Nutritional status.

\section{Kata kunci:}

Perilaku makan;

Siswa SD;

Kesehatan mental anak;

Status gizi.

\author{
ABSTRACT/ ABSTRAK
}

Nutrition is one of the important factors that determine the level of health between physical and mental development. Well greatly affects the concentration and intelligence of children in receiving and absorbing any knowledge obtained at school. The purpose of this study was to identify the relationship between eating behavior and nutritional status with the mental health status of students in Jayapura State Instruction Waena Permai. This research uses quantitative methods with correlation design and data collection techniques used questionnaires and structured interviews. Respondents in this study were all students in grades V and VI with age criteria 10-13 years with a sample of 40 respondents. The result of this study was, the eating behavior of class V and VI respondents most often consumed rice, eggs, fish, water spinach, bananas, and sweet tea. Nutritional status in class V and VI respondents was normal, and most mental health in class V and VI respondents was abnormal. In the conclusion of this study, there is no significant relationship between nutritional status and mental health with a significant value of 0.949 .

\begin{abstract}
Gizi merupakan salah satu faktor penting yang menentukan tingkat kesehatan dan keserasian antara perkembangan fisik dan mental. Gizi yang baik sangat mempengaruhi daya konsentrasi dan kecerdasan anak dalam menerima dan menyerap setiap ilmu yang didapat di sekolah. Tujuan dari penelitian ini adalah untuk mengidentifikasi hubungan antara perilaku makan dan status gizi dengan status kesehatan mental siswa SD Negeri Inpres Waena Permai Kota Jayapura. Penelitian ini menggunakan metode kuantitatif dengan teknik korelasi serta teknik pengambilan data berupa angket/kuesioner dan wawancara terstruktur. Responden dalam penelitian ini adalah semua siswa kelas V dan VI dengan kriteria usia 10-13 tahun dengan jumlah sampel 40 responden. Hasil Penelitian: perilaku makan pada responden kelas $\mathrm{V}$ dan VI ialah, responden paling sering mengonsumsi nasi, telur, ikan, kangkung, pisang dan teh manis. Status gizi terbanyak pada responden kelas V dan VI ialah normal, dan kesehatan mental terbanyak pada responden kelas V dan VI ialah abnormal. Kesimpulan, tidak terdapat hubungan antara status gizi dan kesehatan mental dengan nilai signifikan 0,949 .
\end{abstract}

Corresponding Author:

Jufriana Yuwono Vera Adi

Fakultas Kedokteran dan Ilmu Kesehatan, Universitas Kristen Satya Wacana Salatiga, Indonesia

Email: geloramangalik@uksw.edu

\section{PENDAHULUAN}

Gizi merupakan salah satu faktor penting yang menentukan tingkat kesehatan dan keserasian antara perkembangan fisik dan mental. Gizi yang baik sangat mempengaruhi daya konsentrasi dan kecerdasan anak dalam menerima dan menyerap setiap ilmu yang didapat 
di sekolah. Anak sekolah merupakan sasaran strategis dalam perbaikan gizi masyarakat. Hal ini menjadi penting karena anak sekolah sedang mengalami pertumbuhan secara fisik dan mental yang sangat diperlukan untuk menunjang kehidupannya di masa mendatang (Ningsih dkk., 2016).

Berdasarkan data Riset Kesehatan Dasar (Riskesdas) 2018 menunjukkan prevalensi status gizi pada anak usia 5-12 tahun berdasarkan indikator Indeks Massa Tubuh/Umur (IMT/U) adalah 9.2\%, terdiri dari $2,4 \%$ sangat kurus dan 6,8\% kurus. Prevalensi sangat kurus paling rendah terjadi di Bali $(1,2 \%)$ dan paling tinggi di Nusa Tenggara Timur $(4,6 \%)$. Sebanyak 19 provinsi dengan prevalensi sangat kurus diatas angka nasional, yaitu Nusa Tenggara Barat, Kalimantan Tengah, Papua, Papua Barat, Banten, Kalimantan Selatan, Maluku, Sumatera Selatan, Kalimantan Barat, Riau, Gorontalo, Aceh, Jambi, Kepulauan Riau, Sulawesi Selatan, Sulawesi Tenggara, Maluku Utara, Sulawesi Tengah, dan Nusa Tenggara Timur. Pada tingkat nasional, masalah gemuk pada anak umur 5-12 tahun masih tinggi yaitu $20 \%$, terdiri dari gemuk 15,3\% dan sangat gemuk (obesitas) $15,3 \%$. Prevalensi gemuk terendah di Nusa Tenggara Timur $(3,7 \%)$ dan tertinggi di Papua (15,3\%). Sebanyak 12 provinsi dengan prevalensi sangat gemuk diatas angka nasional yaitu Kalimantan Timur, Banten, Bali, Kepulauan Riau, Jambi, Bengkulu, Bangka Belitung, Jawa Timur, Aceh, DI Yogyakarta, DKI Jakarta dan Papua (Kemenkes RI, 2018).

Beberapa penelitian juga menunjukkan bahwa anak-anak yang tidak sarapan dan kelaparan berperilaku lebih buruk di sekolah, seperti, berkelahi dan jarang masuk sekolah sedangkan perhatian akan meningkat ketika responden sarapan dan makan makanan bergizi (Mental Health Foundation, 2017). Penelitian lain juga mengungkapkan bahwa, jika anak mengalami gizi yang kurang terpenuhi, maka dampak negatif yang akan muncul ialah lambatnya pertumbuhan badan, rawan terhadap penyakit, menurunya tingkat kecerdasan, dan terganggunya mental anak (Annajiah, 2017). Penelitian lain juga mengatakan bahwa jika anak mengalami gizi buruk maka anak akan mudah menderita salah mental, sukar berkonsentrasi, rendah diri, dan prestasi belajar menjadi rendah (Syatyawati, 2013). Sehingga dapat dikatakan bahwa gizi yang baik dapat membuat kesehatan mental anak baik sedangkan gizi yang kurang baik, dapat menimbulkan masalah gangguan kesehatan mental pada anak, yang di sebabkan oleh faktor kemiskinan dan pendapatan yang kurang sehingga anak-anak jarang mendapatkan gizi yang seharusnya (Wallace, 2013).

Menurut Mental Health Foundation di Amerika, anak yang sehat secara mental mempunyai kemampuan untuk; (a) berkembang secara psikologis, emosional, kreatif, intelektual dan spiritual; (b) mengambil inisiatif, mengembangkan dan mempertahankan kelangsungan relasi personal yang memuaskan; (c) memanfaatkan kesendirian (solitude) dan menikmatinya; (e) menjadi sadar akan responden lain dan berempati dengan mereka; (f) bermain dan belajar; $(\mathrm{g})$ mengembangkan rasa benar dan salah dan (h) menghadapi masalah dan kemalangan serta belajar dari peristiwa-peristiwa ini, dalam cara-cara yang selaras dengan tingkat usia mereka (Suryanto, dkk., 2017).

Tujuan dari penelitian ini adalah untuk mengidentifikasi hubungan antara perilaku makan dan status gizi dengan status kesehatan mental siswa SD negeri inpres waena permai kota jayapura. Dengan demikian, dapat dikatakan bahwa penelitian ini dilakukan agar dapat melihat bahwa, apakah penelitian ini terdapat hubungan yang signifikan atau tidak, sehingga hasil yang didapat dari penelitian ini ialah tidak terdapat hubungan yang signifikan antara perilaku makan dan status gizi dengan kesehatan mental siswa $\mathrm{SD}$.

\section{METODE}

Peneliti menggunakan metode kuantitatif dengan teknik korelasi. Teknik pengambilan data berupa angket/kuesioner, dan juga melalui wawancara. Angket/kuesioner untuk Perilaku makan/FFQ berjumlah 105 pertanyaan. Pertanyaan untuk angket/kuesioner Kekuatan dan Kesulitan pada anak berjumlah 25 pertanyaan, pada angket/kuesioner kekuatan dan kesulitan pada anak, scoring normal dengan nilai (0-15), scoring Borderline/sedang dengan nilai (16-19), sedangkan scoring abnormal dengan nilai (2040). Peneliti juga menggunakan metode pengumpulan data berupa wawancara terstruktur, pengukuran antropometri, sedangkan untuk penentuan status gizi menggunakan IMT/U dan untuk penilaian status gizi anak sendiri menggunakan Standar Antropometri Penilaian Status Gizi Anak. Penelitian ini menggunakan teknik sampel berupa teknik total sampling. Total Sampling adalah teknik pengambilan sampel dimana jumlah sampel sama dengan populasi, dengan jumlah sampel dan populasi yaitu berjumlah 40 responden, dan semua siswa kelas $\mathrm{V}$ dan VI dengan kriteria umur berusia 10-13 
tahun yang menjadi responden. Teknik analisis data berupa analisis bivariat, yaitu untuk mengetahui adanya hubungan antara variabelvariabel terikat $\left(\mathrm{X}_{1}-\mathrm{X}_{3}\right)$ dengan variabel bebas $\left(\mathrm{Y}_{1}\right)$ (Saryono, 2008). Penelitian ini menggunakan uji statistik chi square dan uji korelasi ganda. Uji statistik chi square menggunakan tingkat kemaknaan 95\% $(\alpha=0,05)$.

Penelitian ini telah mendapatkan Persetujuan Etik (Ethical Approval) dengan Nomor 145/PE/KEPK.UKSW/2019 oleh Komite Etik Penelitian Kesehatan Fakultas Kedokteran dan Ilmu Kesehatan Universitas Kristen Satya Wacana Salatiga.

\section{HASIL}

Tabel 1. Karakteristik Responden Penelitian Kelas V dan VI

\begin{tabular}{lrr}
\hline \multicolumn{1}{c}{ Karakteristik } & n & \% \\
\hline Usia Responden Kelas V & & \\
10 & 8 & 40 \\
11 & 7 & 35 \\
12 & 5 & 25 \\
13 & 0 & 0 \\
Jenis Kelamin & & \\
Laki-laki & 11 & 55 \\
$\quad$ Perempuan & 9 & 45 \\
Usia Responden Kelas VI & & \\
10 & 1 & 5 \\
11 & 3 & 15 \\
12 & 15 & 75 \\
13 & 1 & 5 \\
Jenis Kelamin & & \\
Laki-laki & 9 & 45 \\
Perempuan & 11 & 55 \\
\hline
\end{tabular}

Berdasarkan tabel 1 mayoritas responden kelas $\mathrm{V}$ berada pada kelompok usia 10 tahun yaitu $40 \%$ (8 responden), lalu diikuti dengan usia 11 tahun yaitu $35 \%$ (7 responden) dan $0 \%$ pada usia 13 tahun, dan persentase laki-laki lebih banyak dibanding perempuan, yaitu 55\% (11 responden) dan jumlah responden laki-laki pada kelas $\mathrm{V}$ berjumlah 11 responden dan perempuan berjumlah 9 responden, sehingga jika di total, jumlah responden laki-laki dan perempuan pada kelas V berjumlah 20 responden. Mayoritas responden pada kelas VI berada pada kelompok usia 12 tahun yaitu $75 \%$ (15 responden), dan 10 tahun yaitu $5 \%$ (1 responden), serta $1 \%$ (1 responden) pada usia 13 tahun, dan jumlah responden laki-laki pada kelas VI berjumlah 9 responden dan perempuan berjumlah 11 responden, sehingga jika di total, jumlah responden laki-laki dan perempuan pada kelas $\mathrm{V}$ berjumlah 20 responden.
Tabel 2. Kesehatan Mental Responden Kelas

\begin{tabular}{lrr} 
V dan VI & & \\
\hline Kesehatan Mental & n & \% \\
\hline Kelas V & & \\
Normal & 1 & 5 \\
Borderline & 1 & 5 \\
Abnormal & 18 & 90 \\
\hline Kelas VI & & \\
Normal & 0 & 0 \\
Borderline & 2 & 10 \\
Abnormal & 18 & 90 \\
\hline
\end{tabular}

Berdasarkan tabel 2 kesehatan mental responden kelas V dan kelas VI SD sama yaitu abnormal dengan persentase $90 \%$, dengan jumlah responden yang sama juga yaitu 18 responden untuk masing- masing kelasnya, namun terdapat perbedaan pada aspek lain, yaitu untuk kelas $\mathrm{V}$ kesehatan mental normal sebesar 5\% (1 responden) dan sedang yaitu 5\% (1 responden) sedangkan pada kelas VI, kesehatan mental yang tinggi yaitu $10 \%$ (2 responden), sehingga terlihat jelas sekali bahwa ada perbandingan/perbedaan diantara 2 kelas ini.

$\begin{aligned} & \text { Tabel 3. Kuesioner Kekuatan dan Kesulitan } \\
& \text { Pada Anak }\end{aligned}$
\begin{tabular}{lll}
\hline \multicolumn{1}{c}{ Kesehatan Mental } & n & \% \\
\hline Kelas V dan VI & & \\
Skala Masalah Emosional & 240 & 23 \\
Skala Melakukan Masalah & 201 & 19 \\
Skala Hiperaktif & 175 & 16 \\
Skala Masalah Teman Sebaya & 159 & 15 \\
Skala Anti Sosial & 291 & 27 \\
\hline
\end{tabular}

Pada tabel 3, pengukuran aspek kekuatan dan kesulitan pada anak (strenghs and difficulties questionnaire) ini dilakukan dengan menggunakan kuesioner singkat mengenai tingkah laku anak usia 3-16 tahun yang bertujuan mencerminkan proporsi anak-anak di setiap kategori dalam dataset yang lebih besar. Dengan demikian dapat dilihat skala mana yang banyak dialami atau dirasakan oleh setiap responden dari masing-masing kelas. Berdasarkan grafik diatas, skala masalah terbanyak yang terjadi di kelas $\mathrm{V}$ dan VI ialah Skala Anti Sosial dengan dengan jumlah persentase 27\%, lalu diikuti dengan Skala Masalah Emosional dengan jumlah persentase $23 \%$, sedangkan yang paling terendah atau dibawah rata-rata ialah Skala Masalah Teman Sebaya, yaitu dengan jumlah persentase $15 \%$. 
Tabel 4.Indeks Massa Tubuh

\begin{tabular}{lrr}
\hline \multicolumn{1}{c}{ IMT } & n & \% \\
\hline Kelas V & & \\
Sangat Kurus & 0 & 0 \\
Kurus & 0 & 0 \\
Normal & 16 & 80 \\
Gemuk & 4 & 20 \\
Obesitas & 0 & 0 \\
\hline Kelas VI & & \\
Sangat Kurus & 4 & 20 \\
Kurus & 2 & 10 \\
Normal & 12 & 60 \\
Gemuk & 2 & 10 \\
Obesitas & 0 & 0 \\
\hline
\end{tabular}

Berdasarkan tabel 4, IMT terbanyak pada responden kelas $\mathrm{V}$ ialah normal, yaitu dengan persentase $80 \%$ (16 responden), dan yang gemuk dengan persentase yaitu 20\% (4 responden), lalu IMT terbanyak pada kelas VI ialah normal, dengan persentase $60 \%$ (12 responden), sedangkan untuk kurus $10 \%$ ( 2 responden), dan gemuk 10\% (2 responden).

\section{Pola Makan Responden Kelas V dan VI}

Konsumsi terbanyak pada kelompok pangan serelia dan umbi-umbian ialah nasi dengan total 15,75 kali per minggu, sedangkan konsumsi pangan terendah ialah lontong dengan total 0,003 kali per minggu, selanjutnya pada konsumsi pangan sayur-sayur, konsumsi tertinggi ialah sayur kangkung dengan total 2,37 dan terendah ialah sayur genjer dengan total 0,006, selanjutnya pada konsumsi minyak dan lemak yang tertinggi ialah minyak goreng kemasan dengan total 3,42 dan terendah ialah margarin 0,025 dan pada konsumsi pangan minuman, yang tertinggi ialah teh manis dengan total 4,806 dan konsumsi terendah ialah juice buah dengan total 0,06 .
Tabel 5. Rata-Rata Frekuensi Konsumsi Pangan Berdasarkan Sekelompok Pangan

\begin{tabular}{|c|c|}
\hline \multirow[t]{2}{*}{ Kelompok Pangan } & $\begin{array}{c}\text { Frekuensi } \\
(\mathrm{x} / \text { minggu })\end{array}$ \\
\hline & Total $(n=40)$ \\
\hline \multicolumn{2}{|l|}{ Serelia dan Umbi-umbian } \\
\hline Nasi & 15,75 \\
\hline Mie Instant & 1,07 \\
\hline Ubi Rebus & 0,5 \\
\hline Bubur Nasi/Bubur Ayam & 0,005 \\
\hline Lontong & 0,003 \\
\hline \multicolumn{2}{|l|}{ Kacang-kacangan } \\
\hline Tahu Goreng & 1,32 \\
\hline Kecap & 1,25 \\
\hline Tempe Goreng & 1,21 \\
\hline Kacang Goreng & 0,015 \\
\hline Pepes Tahu & 0,013 \\
\hline \multicolumn{2}{|l|}{ Daging, Unggas dan Olahan } \\
\hline Telur Ayam Goreng ( & \\
\hline dadar/ceplok) & 1,95 \\
\hline Sosis Ayam & 0,22 \\
\hline Telur Ayam Rebus & 0,21 \\
\hline Daging sapi goreng/empal & 0,012 \\
\hline Rendang Sapi & 0,001 \\
\hline \multicolumn{2}{|l|}{ Ikan dan Olahannya } \\
\hline Ikan laut goreng & 0,28 \\
\hline Ikan tawar goreng & 0,215 \\
\hline Ikan tawar bakar & 0,013 \\
\hline Ikan laut pepes & 0,007 \\
\hline Teri Goreng & 0,006 \\
\hline \multicolumn{2}{|l|}{ Sayur-sayur } \\
\hline Kangkung & 2,37 \\
\hline Bayam & 1,05 \\
\hline Dan Ubi Jalar & 0,538 \\
\hline Labu Kuning & 0,02 \\
\hline Genjer & 0,006 \\
\hline \multicolumn{2}{|l|}{ Buah-buahan } \\
\hline Pisang & 0,35 \\
\hline Pepaya & 0,222 \\
\hline Jeruk & 0,134 \\
\hline Rambutan & 0,011 \\
\hline Alpokat & 0,002 \\
\hline \multicolumn{2}{|l|}{ Susu dan Olahannya } \\
\hline Ice Cream & 0,311 \\
\hline Yogurt & 0,131 \\
\hline Susu kental manis & 0,113 \\
\hline Keju & 0,09 \\
\hline Susu Segar & 0,04 \\
\hline \multicolumn{2}{|l|}{ Minyak dan Lemak } \\
\hline Minyak goreng kemasan & 3,42 \\
\hline Mentega & 0,025 \\
\hline Margarin & 0,025 \\
\hline \multicolumn{2}{|l|}{ Makanan jadi/kue/jajanan } \\
\hline Permen & 2,82 \\
\hline Chiki dan sejenisnya & 1,931 \\
\hline Biskit & 0,59 \\
\hline Coklat & 0,316 \\
\hline Kue dari Beras & 0.075 \\
\hline \multicolumn{2}{|l|}{ Minuman } \\
\hline Teh Manis & 4,81 \\
\hline Sirop & 1,05 \\
\hline Pop ice dan sejenisnya & 0,831 \\
\hline Minuman bersoda & 0,116 \\
\hline Juice buah & 0,06 \\
\hline
\end{tabular}




\section{Hubungan Antara Status Gizi dengan Kesehatan Mental}

Tabel 6. Hubungan Antara Status Gizi dengan Kesehatan Mental

\begin{tabular}{|c|c|c|c|c|c|}
\hline \multirow[b]{2}{*}{ IMT/U } & \multicolumn{3}{|c|}{ Kesehatan Mental } & \multirow[b]{2}{*}{ Total } & \multirow[b]{2}{*}{ p-value } \\
\hline & Normal & Borderline & Abnormal & & \\
\hline $\begin{array}{l}\text { Sangat } \\
\text { Kurus }\end{array}$ & 0 & 0 & 4 & 4 & \\
\hline Kurus & 0 & 0 & 2 & 2 & \\
\hline Normal & 1 & 2 & 25 & 28 & 0,949 \\
\hline Gemuk & 0 & 1 & 5 & 6 & \\
\hline Total & 1 & 3 & 36 & 40 & \\
\hline
\end{tabular}

Hasil uji hipotesis dari hubungan antara status gizi dengan kesehatan mental adalah dengan nilai sig 0,949 yang berarti $\mathrm{H} 0$ diterima dan $\mathrm{H} 1$ ditolak, yang artinya tidak ada hubungan yang signifikan antara status gizi dan kesehatan mental.

\section{PEMBAHASAN}

Kesehatan Mental serta Kekuatan dan
Kesulitan pada Anak

Hasil penelitian menunjukan bahwa, siswa yang memiliki total skor SDQ boderline/sedang dan abnormal lebih banyak pada kelas VI dibanding kelas V. Persentase responden pada kelas V dan VI yang mempunyai skala anti sosial terbilang cukup tinggi, dan skala masalah emosional yang mana bila di nilai dalam SDQ hampir sama dngan gejala depresi yang meliputi, gejala somatik, perasaan tidak bahagia, cemas, ketakutan dan kurang percaya diri, Sehingga hasil yang didapat dari SDQ, bahwa skala anti sosial dan skala masalah emosional bisa sangat mempengaruhi kesehatan mental mereka (Utami, 2012).

Untuk dapat mengetahui/mendukung hal tersebut, terdapat aspek lain juga yang dapat dilihat, seperti menurut Dewi (2012), tidak hanya dari segi psikologis dan medis, tetapi juga dapat melibatkan faktor interpersonal, keluarga, masyarakat, dan hubungan sosial. Terdapat juga Pendekatan Biologis dengan mempelajari fungsi otak, kelenjar endokrin, dan fungsi sensoris. Pendekatan tersebut meyakini bahwa kesehatan mental individu sangat dipengaruhi oleh faktor genetik dan kondisi saat ibu hamil, serta faktor eksternal terkait gizi, radiasi, usia, dan komplikasi penyakit. Pendekatan Sosio-Kultural memiliki beberapa pendekatan, yaitu Stratifikasi Sosial yang membahas faktor sosial-ekonomi dan seleksi sosial; Interaksi Sosial yang membahas fungsi dalam suatu hubungan interpersonal (Teori Psikodinamik, teori rendahnya interaksi sosial seperti isolasi dan kesepian); Teori Keluarga yang mempelajari pengaruh pola asuh, interaksi antar anggota keluarga, dan fungsi keluarga terhadap kesehatan mental individu:Perubahan Sosial yang mengkaitkan perubahan jangka panjang, migrasi, dan industrialisasi, serta kondisi krisis dengan kondisi mental individu. Selain itu, terdapat jenis pendekatan, yaitu Pendekatan Lingkungan yang memiliki dua dimensi, yakni Dimensi Lingkungan Fisik yang terkait dengan ruang, waktu, dan sarana (gizi) yang menyertai dan Dimensi Lingkungan Kimiawi dan Biologis yang terkait dengan polusi, radiasi, virus dan bakteri, serta populasi makhluk hidup lain (Dewi, 2012).

Hal ini juga sejalan dengan penelitian Utami (2012), yaitu berbagai faktor yang dapat meningkatkan atau menurunkan risiko kelainan mental, emosional dan perilaku pada anak dan remaja antara lain ialah, kompetensi dan karakteristik individu, keluarga, kualitas sekolah dan karakteristik di level komunitas. Faktorfaktor tersebut cenderung memiliki efek kumulatif, faktor risiko yang besar akan meningkatkan kemungkinan dampak negatif sedangkan sejumlah besar faktor protektif akan menurunkan kemungkinan terjadinya dampak negatif. Dapat disimpulkan, kondisi mental siswa tersebut tidak dapat langsung dikatakan sedemikian rupa karena harus ditinjau lebih lanjut dari berbagai aspek (Utami, 2012).

\section{Indeks Massa Tubuh (IMT)}

Status gizi adalah tanda-tanda yang diakibatkan oleh keseimbangan antara pemasukan dan pengeluaran gizi oleh tubuh. Status gizi merupakan ekspresi dari keseimbangan dalam bentuk variabel tertentu. Seseorang dikatakan mencapai pertumbuhan optimal, apabila dapat mencapai standar pertumbuhan yang seharusnya dicapai pada usia tersebut, salah satunya direpresentasikan oleh status gizi, yaitu normal, gizi lebih atau gizi kurang. Antropometri merupakan indikator yang umum digunakan untuk pengukuran gizi. Status gizi yang diukur secara antropometrik dapat 
diketahui melalui beberapa indeks, diantaranya BB dan TB terhadap usia, serta BB terhadap TB. (Fikawati, dkk., 2017).

Dalam penelitian ini status gizi diperoleh dengan pengukuran antropometri yaitu Indeks Massa Tubuh/Umur (IMT/U) yang merupakan salah satu perwujudan status kesehatan seseorang, sehingga terlihat bahwa, status gizi terbanyak pada responden kelas $\mathrm{V}$ dan VI ialah normal, tetapi ada juga beberapa responden yang mempunyai status gizi sangat kurus, kurus dan gemuk. Status gizi sangat kurus/kurus disebabkan oleh banyak faktor, beberapa diantaranya ialah asupan gizi yang kurang tepat, kurangnya ketersediaan pangan, memilih-milih makanan, pola asuh anak kurang memadai dll, sehingga jika tidak diatasi dapat menimbulkan berbagai penyakit seperti perkembangan kognitif, kemampuan belajar menurun, kesehatan reproduksi yang nantinya berakibat pada produktivitas kerja di masa yang akan datang, dan pada status gizi gemuk terjadi akibat mengonsumsi kalori lebih banyak dari yang dibutuhkan oleh tubuh faktor utama adalah ketidakseimbangan asupan energi dengan keluarnya energi, asupan energi tinggi apabila konsumsi makanan berlebihan sedangkan keluarnya energi jadi rendah bila metabolisme tubuh dan aktivitas fisik rendah sehingga hal tersebut bisa memicu penyakit dimasa yang akan datang seperti obesitas, hipotiroidisme, dan beberapa kelainan saraf yang dapat menyebabkan seseorang banyak makan. Status gizi normal adalah suatu kondisi dimana asupan gizi yang masuk dan keluar seimbang, sehingga tidak terdapat kesenjangan dalam status gizinya. Asupan gizi yang baik berperan penting dalam mencapai pertumbuhan badan yang optimal. Pertumbuhan badan yang optimal ini mencakup pertumbuhan otak yang sangat menentukan kecerdasan seseorang. Dampak akhir dari konsumsi gizi yang baik dan seimbang adalah meningkatnya kualitas sumber daya manusia. (Adriani, dkk., 2012; Sa'adah, dkk., 2014)

Ketika peneliti melakukan penelitian/pengambilan data, peneliti sendiri sudah membuktikan bahwa mereka dapat berkonsentrasi, aktif dan sesekali dapat/bisa menjawab pertanyaan yang diberikan oleh peneliti, sehingga aktivitas belajar-mengajar baik di dalam maupun di luar kelas atau sekolah dapat mereka lakukan dengan baik. Hal ini sejalan dengan teori yang di ungkapkan oleh Khomsan (2004) bahwa status gizi yag baik akan mempengaruhi tingkat kecerdasan dan kemampuan seseorang dalam menangkap pelajaran di sekolah, sehingga seseorang yang memiliki status gizi baik akan memiliki daya tangkap yang lebih baik dan dapat memperoleh prestasi yang baik pula di sekolahnya (Ristiyati, 2014).

\section{Pola Makan Responden}

Terdapat berbagai macam makanan yang sering dikonsumsi dan jarang dikonsumsi oleh para responden karena berbagai macam faktor. Menurut Adriani, dkk (2012) ada beberapa faktor yang dapat mempengaruhi pola makan/asupan makanan, antara lain: faktor budaya, agama atau kepercayaan, status sosial ekonomi, personal preference, rasa lapar, nafsu makan, rasa kenyang dan kesehatan. Yang pertama ialah budaya, budaya cukup memegang peranan penting dalam penentuan jenis makanan, sebagai contoh nasi kebanyakan dimakan oleh setiap responden, tetapi responden papua kadang lebih senang memakan umbi-umbian. Agama dan Kepercayaan, agama dan kepercayaan juga memegang peranan penting dalam penentuan jenis makanan, misal agama kristen dalam memakan daging babi tetapi agama islam tidak bisa memakan daging tersebut karena menganggap hal itu sebagai suatu yang haram atau di larang oleh agamanya. Status sosial ekonomi, dapat juga mempengaruhi karena penentuan jenis makanan di pengaruhi oleh status sosial ekonomi, misal responden dengan sosial ekonomi mampu dapat membeli makanan jadi dengan harga yang terbilang cukup mahal tetapi untuk responden kelas menengah ke bawah, tidak sanggup melakukan hal tersebut (Adriani, dkk., 2012).

Personal preference ialah, hal-hal yang disukai dan tidak di sukai sangat berpengaruh terhadap kebiasaan makan seorang, contoh jika dari kecil sang ayah tidak suka makan ikan, maka hal tersebut juga dirasakan oleh anaknya sehingga perasaan suka dan tidak suka seorang tergantung asosiasinya terhadap makanan tersebut. Rasa lapar, nafsu makan, dan rasa kenyang, ialah sensasi yang kurang menyenangkan karena berhubungan dengan kekurangan makanan, sebaliknya nafsu makan merupakan perasaan menyenangkan ketika seorang ingin makan sehingga pengaturan dan pengontrolan mekanisme lapar, nafsu makan, dan rasa kenyang diatur oleh sistem saraf yaitu hipotalamus, dan yang terakhir ialah kesehatan, yang mana kesehatan seseorang berpengaruh kepada kebiasaan makan. Sariawan atau gigi yang sakit sering kali membuat individu memilih makanan yang lembut, sehingga menyebabkan 
responden yang kesulitan menelan lebih memilih untuk menahan rasa lapar (Adriani, dkk., 2012).

Menurut Worthington (2000) dikatakan bahwa hal lain yang mempengaruhi pola makan seseorang di bagi menjadi dua, yaitu internal yang terdiri dari IMT, umur, jenis kelamin, pengetahuan gizi, keyakinan, nilai dan norma, pemilihan dan arti makanan, kebutuhan fisiologis tubuh, body image/citra diri, konsep diri, perkembangan psikososial, kesehatan (riwayat penyakit), dan faktor eksternal meliputi tingkat ekonomi keluarga, pekerjaan, pendidikan orang tua, sosial dan budaya, peran orang tua, teman sebaya, pengalaman individu, pengaruh media. Sehingga dapat di simpulkan bahwa yang menyebabkan responden jarang mengonsumsi atau hampir tidak pernah mengonsumsi makananmakanan tersebut ialah karena beberapa faktor yang sudah disebutkan atau dijelaskan di atas (Putri, 2015).

\section{Hubungan antara Status Gizi dengan Kesehatan Mental}

Dalam penelitian ini, tidak ditemukan hubungan yang signifikan antara status gizi dan kesehatan mental. Hal ini dimungkinkan terjadi, karena asupan gizi yang diterima atau di konsumsi, baik dan terpenuhi secara pangan. Makanan merupakan sumber penghasil energi dan zat gizi untuk bekerjanya proses metabolisme dalam tubuh, sehingga manusia dapat tumbuh dengan baik sehingga hal tersebut juga dapat mempengaruhi status gizi seseorang. Seseorang yang sehat dan mempunyai status gizi yang baik memiliki daya fikir dan aktivitas fisik yang baik sehingga hal ini akan mendukung prestasi dalam belajarnya. Sebagian dari para responden ini biasa mengonsumsi makanan yang bergizi dan mengandung karbohidrat, protein, lemak, vitamin dan mineral (Ningsih, dkk., 2016 ).

Menurut Fikawati (2017), karbohidrat mempunyai fungsi yaitu sebagai sumber energi utama bagi otak dan berbagai proses metabolisme dalam otak. Protein digunakan sebagai zat pembangun dan pengganti jaringan yang rusak, dan juga sebagai pembentuk neurotransmiter (pengatur suasana hati). Lemak, otak manusia terdiri hampir $60 \%$ lemak. Asam lemak adalah salah satu molekul yang paling penting dalam menentukan integritas dan kemampuan otak. Vitamin dan mineral berfungsi untuk membantu kerja otak sehingga ketika peneliti melakukan pengambilan data, peneliti sendiri sudah membuktkan bahwa para responden dapat melakukan aktivitas mereka baik di dalam maupun diluar kelas ataupun sekolah dengan baik, sehingga walaupun status kesehatan mental terbanyak ialah di atas rata-rata tetapi jika status gizi responden baik/normal maka itu tidak menjadi suatu masalah bagi para responden untuk melakukan ativitasnya seperti biasa, baik di luar maupun di dalam sekolah Hal ini dikarenakan terdapat juga beberapa faktor yang mendukung status gizi dan kesehatan mental diantaranya adalah jenis kelamin, tingkat obesitas, umur, dan status sosial ekonomi. Kebanyakan responden mempunyai keluarga yang berada pada status sosial ekonomi rendah namun tidak membuat responden ini kekurangan asupan gizi. Walaupun orang tua/keluarga mereka tidak mempunyai sosial ekonomi yang baik untuk memberi makan yang begitu terpenuhi, tetapi hal itu dapat tergantikan dengan hasil kebun mereka sendiri, misalnya umbi-umbian, buah-buahan, ataupun sayur-sayuran. Untuk itu, mereka masih dapat mempertahankan asupan gizi yang diterima karena gizi merupakan salah satu faktor penting yang menentukan tingkat kesehatan dan keserasian antara perkembangan fisik dan mental (Fikawati, dkk., 2017).

Hal ini sejalan dengan pernyataan Mental Health Foundation di Amerika, anak yang sehat secara mental mempunyai kemampuan untuk; (a) berkembang secara psikologis, emosional, kreatif, intelektual, dan spiritual; (b) mengambil inisiatif, mengembangkan dan mempertahankan kelangsungan relasi personal yang memuaskan; (c) memanfaatkan kesendirian (solitude) dan menikmatinya; (e) menjadi sadar akan orang lain dan berempati dengan mereka; (f) bermain dan belajar; (g) mengembangkan rasa benar dan salah;dan (h) menghadapi masalah dan kemalangan serta belajar dari peristiwa-peristiwa ini dalam cara-cara yang selaras dengan tingkat usia mereka (Suryanto, dkk., 2017)

Berdasarkan hasil dan analisis, dapat dikatakan bahwa status gizi berdasarkan indeks Indeks Massa Tubuh/Umur (IMT/U) dan konsumsi makan bukan satu-satunya faktor yang mempengaruhi kesehatan mental anak karena masih banyak faktor lain yang tidak diteliti dalam penelitian ini seperti lingkungan dan faktor belajar lainnya (Sa'adah, dkk., 2014).

\section{SIMPULAN}

Dalam penelitian ini tidak terdapat hubungan antara status gizi dengan kesehatan mental. Selain di pengaruhi oleh status gizi, penelitian antara status gizi dan kesehatan mental ini juga dipengaruhi oleh perilaku makan sehingga hasil yang didapat pun tidak terdapat 
hubungan yang saling mempengaruhi. Hal ini dimungkinkan terjadi, karena asupan gizi yang diterima atau dikonsumsi, sesuai dan seimbang. Seseorang yang sehat dan mempunyai status gizi

\section{DAFTAR PUSTAKA}

Adriani, A., B, W., \& M, S. (2012). Pengantar Gizi Masyarakat (Edisi Ke 1). Penerbit Kencana.

Annajiah, F. (2017). Upaya Peningkatan Asupan Nutrisi Pada Anak Toodler Dengan Gizi Buruk. Karya Tulis Ilmiah. Surakarta: Universitas Muhammadiyah Surakarta.http://eprints.ums.ac.id/52268/5/ fiah.pdf

Dewi, K. S. (2012). BUKU AJAR KESEHATAN MENTAL. UPT UNDIP Press Semarang.

Fikawati, S, Syafiq A, Veratamala, A. (2017). Gizi Anak Dan Remaja (Edisi 1). PT Raja Grafindo Persada.

Kemenkes RI. (2018). Laporan Hasil Riset Kesehatan Dasar (Riskesdas) Indonesia tahun 2018. Jakarta: Badan Penelitian dan Pengembangan Kesehatan. (pp. 182-183).

Khomsan, A. (2004). Pangan dan Gizi untuk Kesehatan. Jakarta: PT. Raja Grafindo Persada

Mental Health Foundation. (2017). Food for thought: Mental Health and Nutrition Briefing-Policy Briefing. https://www.mentalhealth.org.uk/sites/defa ult/files/food-for-thought-mental-healthnutrition-briefing-march-2017.pdf

Ningsih, Y., Suyanto, \& T, R. (2016). Gambaran Status Gizi Pada Siswa Sekolah Dasar Kecamatan Rangsang Kabupaten Kepulauan Meranti. Jom Fk, 3(2), 1-12. https://jom.unri.ac.id/index.php/JOMFDO K/article/view/9768/0

Putri, A. Y. (2015). Faktor-Faktor yang Berhubungan dengan Pola Konsumsi Makan pada Siswa Madrasah Ibtidaiyah Unwanul Huda di Jakarta Selatan Tahun 2015. [Skripsi]. Jakarta: Program Studi Kesehatan Masyarakat, Fakultas Kedokteran dan Ilmu Kesehatan, Unviersittas Islam Negeri Syarif Hidayatullah. yang baik memiliki daya fikir dan aktivitas fisik yang baik sehingga hal ini akan mendukung prestasi dalam belajarnya.

Ristiyati, I. D. (2014). Hubungan antara Status Gizi dan Prestasi Belajar Murid SD Negeri di Kecamatan Tuntang Kabupaten Semarang. [Skripsi]. Surakarta: Universitas Muhammadiyah Surakarta. http://eprints.ums.ac.id/id/eprint/29444

Sa'adah, R. H., Herman, R. B., \& Sastri, S. (2014). Hubungan Status Gizi dengan Prestasi Belajar Siswa Sekolah Dasar Negeri 01 Guguk Malintang Kota Padangpanjang. Jurnal Kesehatan Andalas, 3(3).

Saryono. (2008). Metodologi Penelitian Kesehatan (Edisi Ke 1). Penerbit Mitra Cendikia Press.

Suryanto, S., Herdiana, I., \& Chusairi, A. (2017). Deteksi Dini Masalah Psikologis Pada Anak Jalanan Oleh Orangtua Asuh di Rumah Singgah. INSAN Jurnal Psikologi Dan Kesehatan Mental, 1(2), 85. https://doi.org/10.20473/jpkm.V1I22016.8 5-96

Syatyawati, R. (2013). Hubungan Antara Status Gizi Dengan Prestasi Belajar Anak Sekolah Dasar Di Desa Grenggeng Kecamatan Karanganyar Kebumen. [Skripsi]. Surakarta: Universitas Muhammadiyah Surakarta. http://eprints.ums.ac.id/24354/12/NASKA H_PUBLIKASI.pdf

Utami, D. P. (2012). Masalah Mental dan Emosional pada Siswa SMP Kelas Akselerasi dan Reguler (Studi Kasus di SMP Negeri 2 Semarang). Media Medika Muda.

Wallace, R. (2013). Nutrition and Mental Health. Penerbit CRC Press.

Worthington, B. S. (2000). Nutrition Throughout The Life Cycle. United, Mcgraw-Hill Book Companies Inc. 